\title{
The Management in the C2-C3 Disc Herniations: A Clinical Study
}

\section{C2-C3 Disk Herniasyonlarında Yönetim: Bir Klinik Çalışma}

\author{
Kadir KOTIL, Ahmet SENGOZ \\ Istanbul Educational and Research Hospital, Department of Neurosurgery, Istanbul, Turkey \\ Presented in: $1^{s t}$ Middle East Neurosurgical Symposia, 8-11 April 2010, Istanbul, Turkey
}

Correspondence address: Kadir KOTIL / E-mail: kadirkotil@gmail.com

\begin{abstract}
AIM: Cervical disc herniation at C2-C3 level is an uncommon condition. In this paper, the management C2-C3 disc herniation and long-term follow-up data of 5 cases is reported.

MATERIAL and METHODS: 1100 patients who have been operated in our department for cervical disc herniation between 2000 and 2009 were studied retrospectively. A total of 5 patients were found to have been operated for $\mathrm{C} 2-\mathrm{C} 3$ herniation in that period . The preferred procedure was anterior cervical discectomy with fusion via retropharyngeal approach.

RESULTS: The incidence of C2-C3 disc herniations was $0.45 \%$. The mean patient age was 63 years (41- 82 years). Upper extremity paresis was the predominant neurological sign. Magnetic resonance images (MRI) revealed central, large and hard disc herniations in 4 cases and accompanying cord signal changes in 4 cases. Successful anterior decompresion was performed in 5 patients. Correct fusion was achieved in 4 patients, and one patient died of an operation unrelated cause early in the follow-up period.

CONCLUSION: C2-C3 disc herniation is rare but may result with severe myelopathy. This kind of herniations tend to be central and large. The present study demonstrates that diagnosis and adequate anterior decompression in C2-C3 disc herniations may provide an excellent outcome. KEYWORDS: C2-3 disc herniation, Upper cervial herniation, Anterior decompression, Cervical disc herniation
\end{abstract}

öz

AMAÇ: C2-3 seviyesinde servikal disk herniasyonları çok nadirdir. Ötorler, C2-3 disk herniasyonlu 5 olguluk bir serinin yönetimi ve takiplerini sunmuşlardır.

YÖNTEM ve GEREÇ: 2000 ve 2007 yılları arasında opere edilen 1100 servikal disk herniasyonlu olgular retrospektif olarak inceleniştir. Otorler, bu retrospektif olguları anterior servikal diskektomi ve füzyon ile opere etmişlerdir.

BULGULAR: C2-3 disk herniasyonlarının insidansı serimizde \%0.45 idi. Ortalama yaş 63 (41-82) idi. Yürüme bozukluğu ve miyelopatiye bağlı değişik derecede spastisite en aşikar bulgulardı. Üst ekstremite parezisi en sık tespit edilen nörolojik bulgu idi. Manyetik rezonans görüntüleme de (MRG) 4 olguda disk santral, dev ve sert disk olma özelliğini yanında spinal kord ödemi ile karakterize idi. 5 olguda anterior servikal diskektomi ve peek kafesle füzyon uygulanmış, bir olguda erken dönemde eksitus olduğundan füzyon 4 olguda tam oluşmuştur.

SONUÇ: C2-3 disk herniasyonları nadirdirler ve şiddetli miyelopatiyle, santral olmaya ve kalsifiye olmaya meyillidirler Bu çalışma C2-3 disk herniasyonları teşhis edildiklerinde yeterli anterior dekompresyonla çok iyi sonuçlar vermektedir.

ANAHTAR SÖZCÜKLER: C2-3 disk herniasyonu, Üst servikal disk herniasyonu, Anterior dekompresyon, Servikal disk herniasyonu

\section{INTRODUCTION}

Cervical disc herniations mostly occur at $\mathrm{C} 5-\mathrm{C} 6$ and $\mathrm{C} 6-\mathrm{C} 7$ levels (2). Thus, most spinal surgeons have experience in lower cervical levels. Anterior surgery of the upper cervical spine is relatively rare, since the majority of cervical spine disorders affect the lower cervical spine.

Due to spondylotic changes and fusion at the lower cervical levels, the upper levels of cervical spine are more mobile than the lower and carry a greater load during cervical spine movement in the elderly $(10,18)$. The overall incidence of disc herniation between $C 2$ and $C 3$ is less than $1 \%$ (1). The literature contains only 13 publications reporting 24 cases of C2-C3 disc herniations (Table I). While lower level cervical disc herniations were seen in young adulthood or adulthood, upper cervical disc herniations were seen in elderly patients $(1,3,5,19,20,22)$. Spondylotic changes and loss of soft-tissue volume in the middle and lower cervical spine make these regions less mobile in elderly patients, overloading the upper levels during cervical movement (20). Anterior cervical disc surgery can be applied in the C3-C4 level disc herniation, but $\mathrm{C} 2-\mathrm{C} 3$ level disc surgery is challenging. A variety of 
Table I: C2-C3 Disc Herniations in the Literature

\begin{tabular}{|c|c|c|c|c|}
\hline Author/Year & $\begin{array}{l}\text { Number } \\
\text { of cases }\end{array}$ & Presentation & $\begin{array}{l}\text { Location of the } \\
\text { disc material }\end{array}$ & Surgical technique \\
\hline Espersen et al., 1984 [9] & 1 & & C2-C3 level & Cloward's technique \\
\hline Jomin et al., 1986 [15] & 2 & & C2-C3 level & $A C D+$ autograft fusion \\
\hline Rosenberg et al., 1991 [8] & 2 & Myelopathy & Retro-odontoid & Posterior transdural \\
\hline Nishizawa et al., 1996 [6] & 1 & Myelopathy & Retro-odontoid & Posterior transdural \\
\hline Chen and Lui, 1997 [10] & 1 & Myelopathy & Retro-odontoid & $\mathrm{TO}+\mathrm{C} 1-\mathrm{C} 2$ fusion \\
\hline Nishizawa et al., 1999 [7] & 3 & Myelopathy & 2 retro-odontoid & Posterior transdural, 1 C2-C3 level \\
\hline Antich et al., 1999 [3] & 1 & Myelopathy & C2-C3 level & $A C D+a u t o g r a f t$ fusion \\
\hline Campbell, 2000 [4] & 1 & Myelopathy & Retro-odontoid & TO \\
\hline Chen, 2000 [5] & 8 & Myelopathy & C2-C3 level & $A C D+$ Fusion \\
\hline Engsberg et al. (25) & 1 & Myelopathy & C2-C3 level & ACD+Fusion \\
\hline Matsuno et al., 2004 [11] & 1 & Myelopathy & Retro-odontoid & Far lateral \\
\hline Deshmukh et al., 2004 [12] & 1 & C2 radiculopathy & Retro-odontoid & Posterior extradural \\
\hline Türe et al., 2007 [16] & 1 & C3 radiculopathy & C2-C3 level & Posterior extradural \\
\hline Present cases (2010) & 5 & myeloradiculopathy & C2-C3 level & $A C D+a u t o g r a f t$ fusion \\
\hline
\end{tabular}

ACD: Anterior cervical discectomy, TO: Transoral odontoidectomy, AEA: Anterolateral extradural approach

techniques have been tried for the surgical treatment of C2-C3 disc herniations, including Cloward's technique (9), anterior discectomy with auto/allograft fusion $(3,5)$, transoral odontoidectomy with or without occipitocervical fusion $(3,4)$, the far lateral approach $(9,16)$, the posterior transdural approach( 19,20,22) and the anterolateral extradural approach (25). Each of these techniques have advantages and disadvantages. We performed a retrospective analysis of 5 consecutive cases surgically treated for cervical myelopathy or myelo-radiculopathy with anterior cervical discectomy and interbody fusion with respect to the clinical and surgical results.

\section{MATERIAL and METHODS}

Between 2000 and 2009, 1100 patients who have been operated in our department for cervical disc herniation were studied retrospectively. A total of 5 patients were found to have been operated for $\mathrm{C} 2-\mathrm{C} 3$ herniation in that period. We reviewed the records of 5 patients who were operated for C2-C3 disc herniation. The information was collected on patient demographics, presenting symptoms, pre- and postoperative neurological status, preoperative imaging, operative technique, duration of follow-up, and postoperative complications. Symmetrical or asymmetrical distribution of the symptoms were also described. Neurological signs; including Hoffman's sign, Lhermitte's sign, Spurling maneuver and Babinski reflex; were evaluated. All patients were investigated by direct roentgenograms, computed tomography (CT) and magnetic resonance imaging (MRI) of the cervical spine. The degree of spinal stenosis was estimated from the axial images of both MRI and CT. All patients underwent anterior discectomy with upper retropharyngeal approach. Intervertebral cages filled with autogenous bone were used for fusion. Clinical and radiographic outcomes were assessed postoperatively and at 6-month intervals. Results were recorded early, at approximately 1 week postsurgery; and late, at 1 year postsurgery.

Demonstrative case: A 42-year-old man presented with face and neck pain and also as numbness at the same area. For the past two years, the patient had a progressive increase in the pain in the right side of his face and at the occipital area. Four months before presentation, the patient started to experience numbness in the right side of his face, mainly over the C2 dermatome. Physical examination revealed hyperreflexia in the upper and lower limbs with positive Babinski and Hoffman's signs bilaterally. The patient had severe upper extremities paresis and right hand dysesthesia that prevented proper examination of the hand. MRI of the cervical spine revealed a disc herniation at the C2-C3 level with signal changes in the spinal cord at the C2-C3 (Figure $1 \mathrm{~A}, \mathrm{~B})$. The patient underwent an anterior C2-C3 discectomy and fusion using an Polyether-ether ketone (PEEK) cage filled with autogenous iliac crest bone graft. The patient had complete resolution of his symptoms within weeks after surgery. Postoperative MRI (Figure 2A, B) and CT (Figure 3A, $B)$ of the cervical spine demonstrated a good decompression and fusion in the late postoperative period (12 months). 


\section{RESULTS}

The mean patient age was 63 years ( $41-82$ years). There was male predominance $(4: 1)$. The mean duration of follow-up was 30.7 months (range 18 and 44 months). The duration of symptoms ranged from 2 to 28 months. There was history of trauma in one of the cases. Most of the patients had perioralfacial numbness, and upper extremity paresis. In four of the patients, the pain was at the lateral occipital and under the oromandibular regions. Occipitocervical pain was detected in two patients who had paracentral disc herniation. Physical
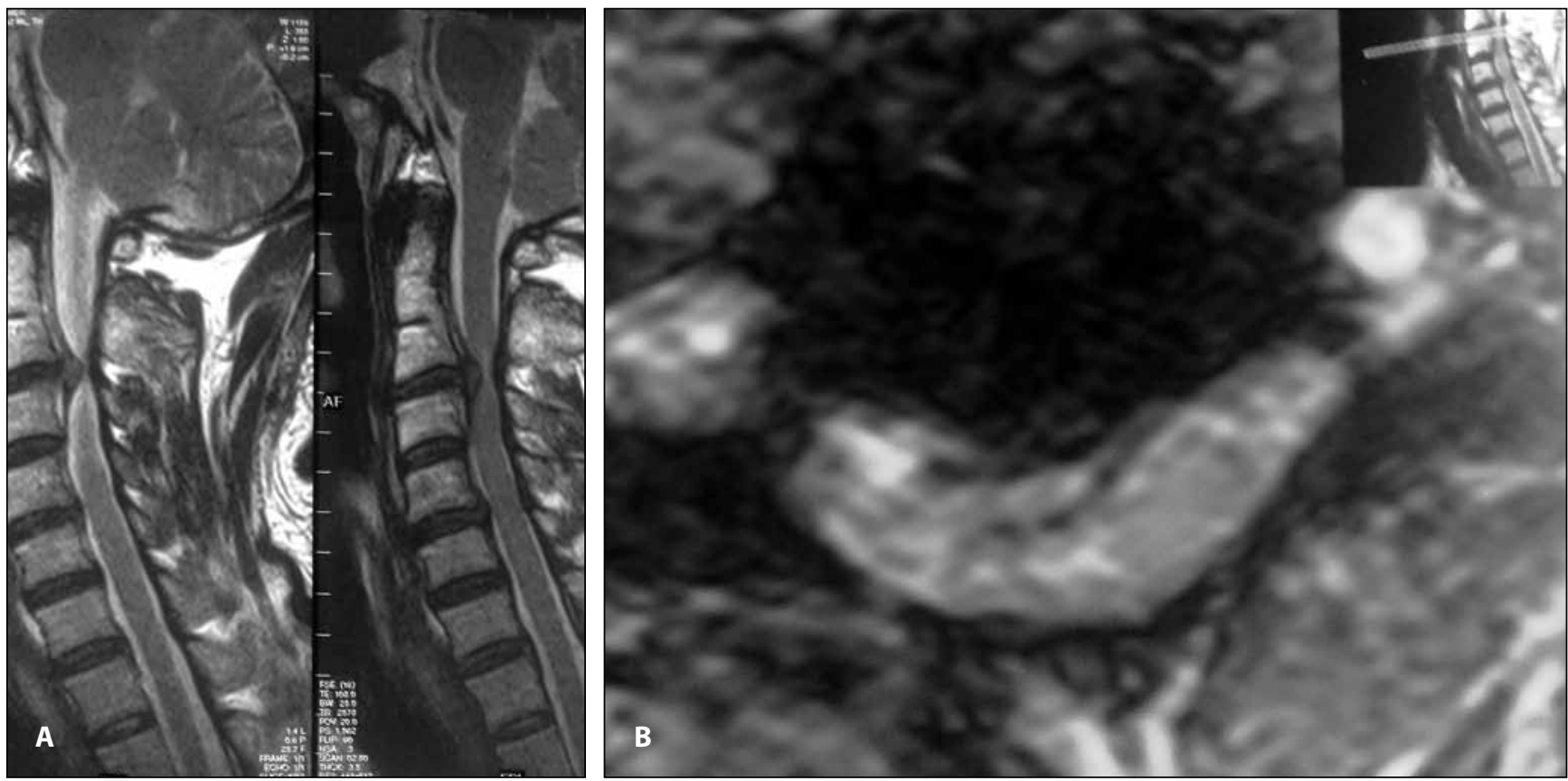

Figure 1: Case 2. Sagittal A) and axial B) magnetic resonance imaging (MRI) taken before cervical discectomy showing evidence of large central disc herniation at the $\mathrm{C} 2-\mathrm{C} 3$ level. The cord compression ratio, derived by dividing sagittal measurement by transverse diameter is very low.
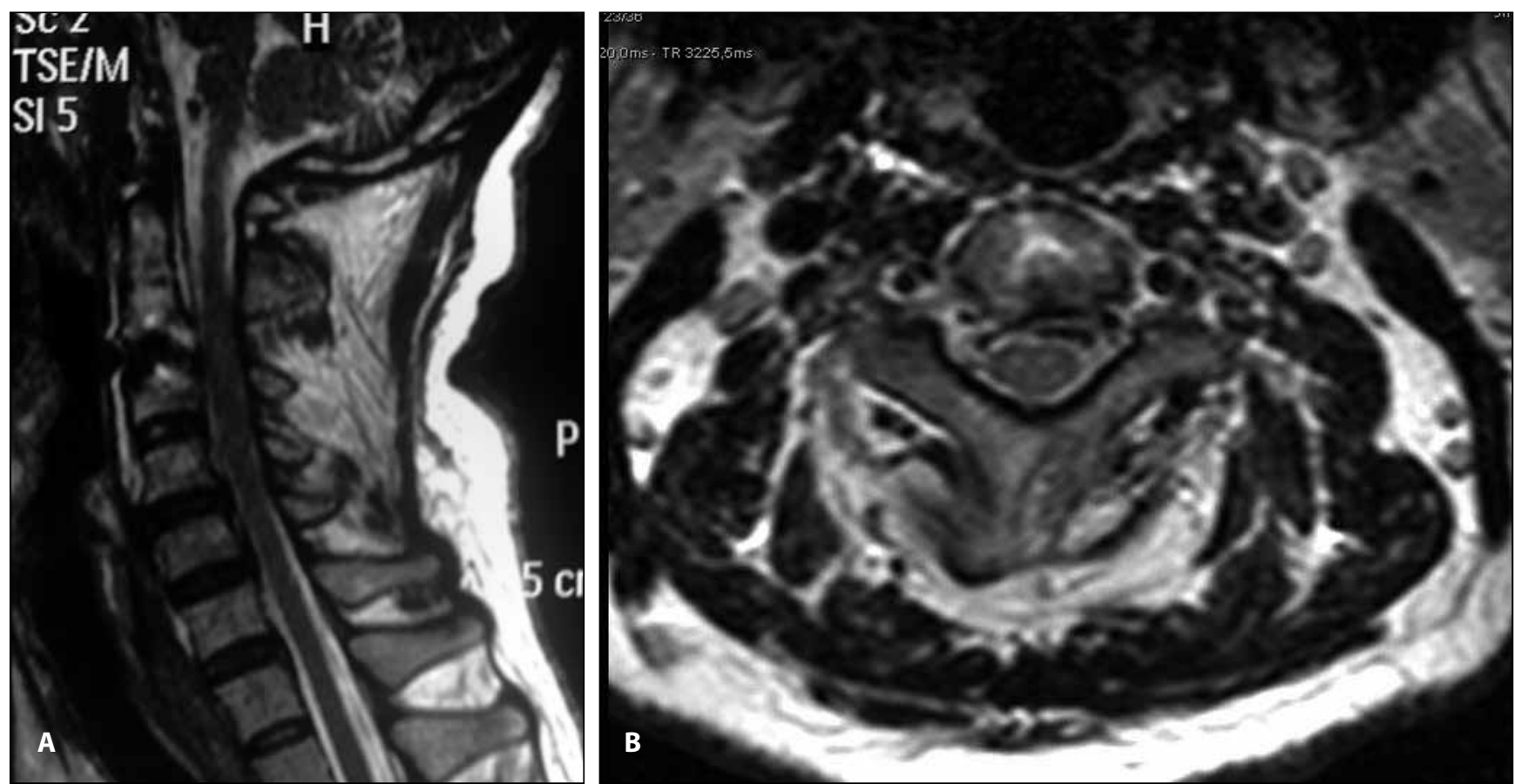

Figure 2: In the postoperative period, T2-weighted sagittal A) and axial B) magnetic resonance images show the decompression and fusion. 
examination revealed pyramidal signs such as clonus; bilateral Hoffman and Babinski signs and hyperreflexia in all of patients who had large central disc herniations.

The summary of symptoms and signs are summarized in Table II. Nurick myelopathic scale were grade 3 in one patient, grade 4 in 3 patients, grade 5 in one patient. Nurick scale is demonstrated in Table III.

In this series, radiological evaluation with MRI revealed all disc herniations. 4 patients had changes in signal intensity in the spinal cord at the level of the disc herniation. 4 of the patients had central, large and hard disc herniation (Figures $4 A, B, C, D)$.

All of the patientswereoperated by an anterior retropharyngeal approach;. The patient underwent an anterior C2-C3 discectomy and fusion using an Polyether-ether ketone (PEEK) cage filled with autogenous iliac crest bone graft. There was no case of symptomatic cage subsidence.

There was retroodontoid migration in none of the cases. The radiological improvement in these patients was eventually

Table II: Clinical Features in 5 Patients with C2-3 Disc Herniations

\begin{tabular}{|c|c|c|c|c|c|c|}
\hline Case. No & Age/ Sex & Pain & myelopathy (Nurick grade) & pyramidal signs & complication & Outcome (Nurick g) \\
\hline 1 & $41 / \mathrm{M}$ & $\mathrm{O}$ & 4 & + & no & $\operatorname{good}(1)$ \\
\hline 2 & $42 / \mathrm{M}$ & 0 & 3 & + & no & $\operatorname{good}(1)$ \\
\hline 3 & $78 / \mathrm{F}$ & $\mathrm{O}, \mathrm{B}$ & 4 & - & no & $\operatorname{good}(0)$ \\
\hline 4 & $66 / M$ & O, & 4 & + & ex & ex \\
\hline 5 & $82 / M$ & $\mathrm{O}, \mathrm{B}$ & 5 & + & no & same (5) \\
\hline
\end{tabular}

O: Occipital, B: Brachialgia.

Table III: Nurick Scale

Grade 0: Signs or symptoms of root involvement but without evidence of spinal cord disease Grade 1: Signs of spinal cord disease but no difficulty in walking Grade 2: Slight difficulty in walking, which did not prevented full-time employment Grade 3: Difficulty in walking Grade 4: Able to walk only with someone else's help or with the aid or frame Grade 5: Chair bound or bedridden
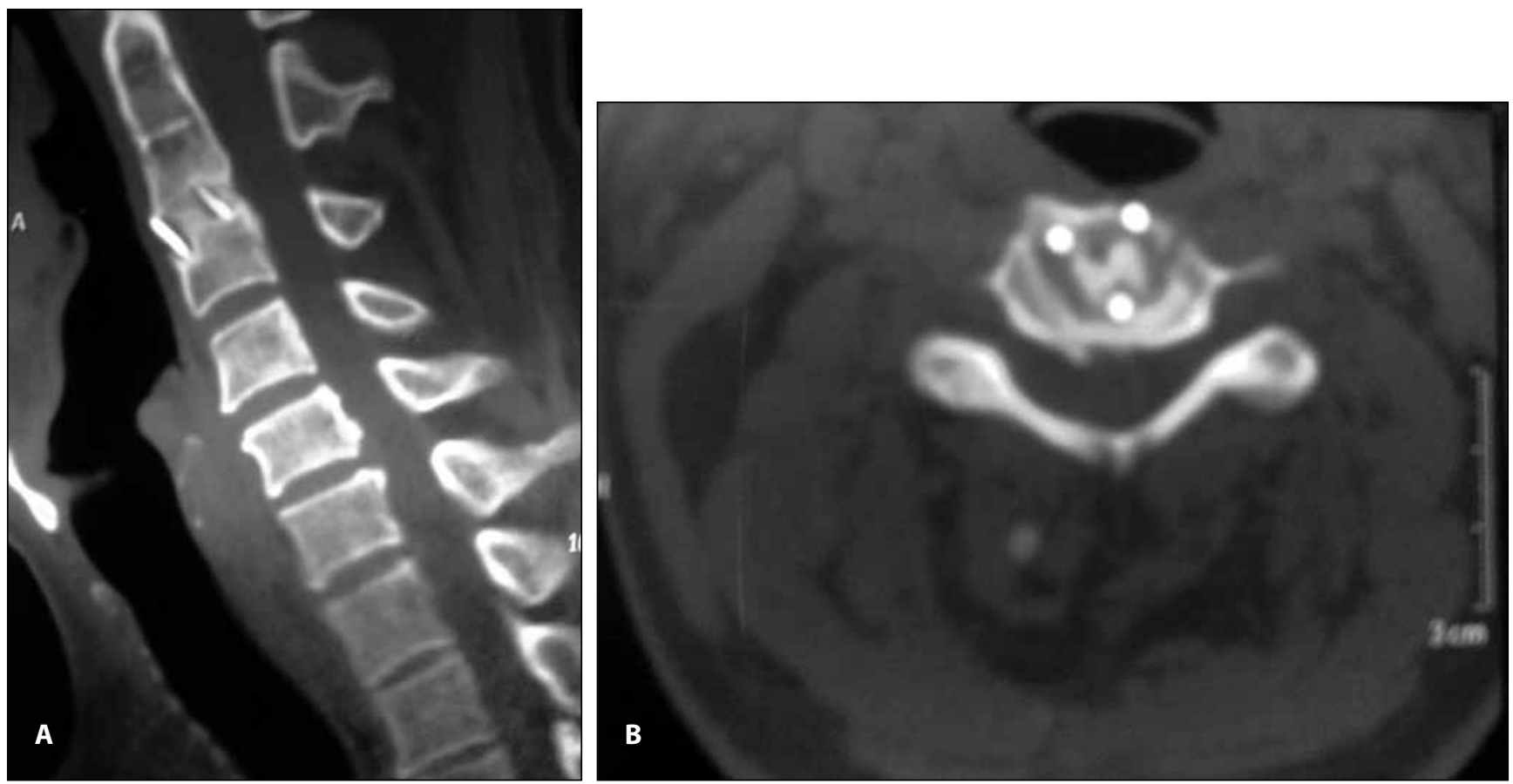

Figure 3: Sagittal A) and axial B) reconstruction computed tomographic (CT) image showing the fusion, and free spinal canal at the C2-C3 level. 

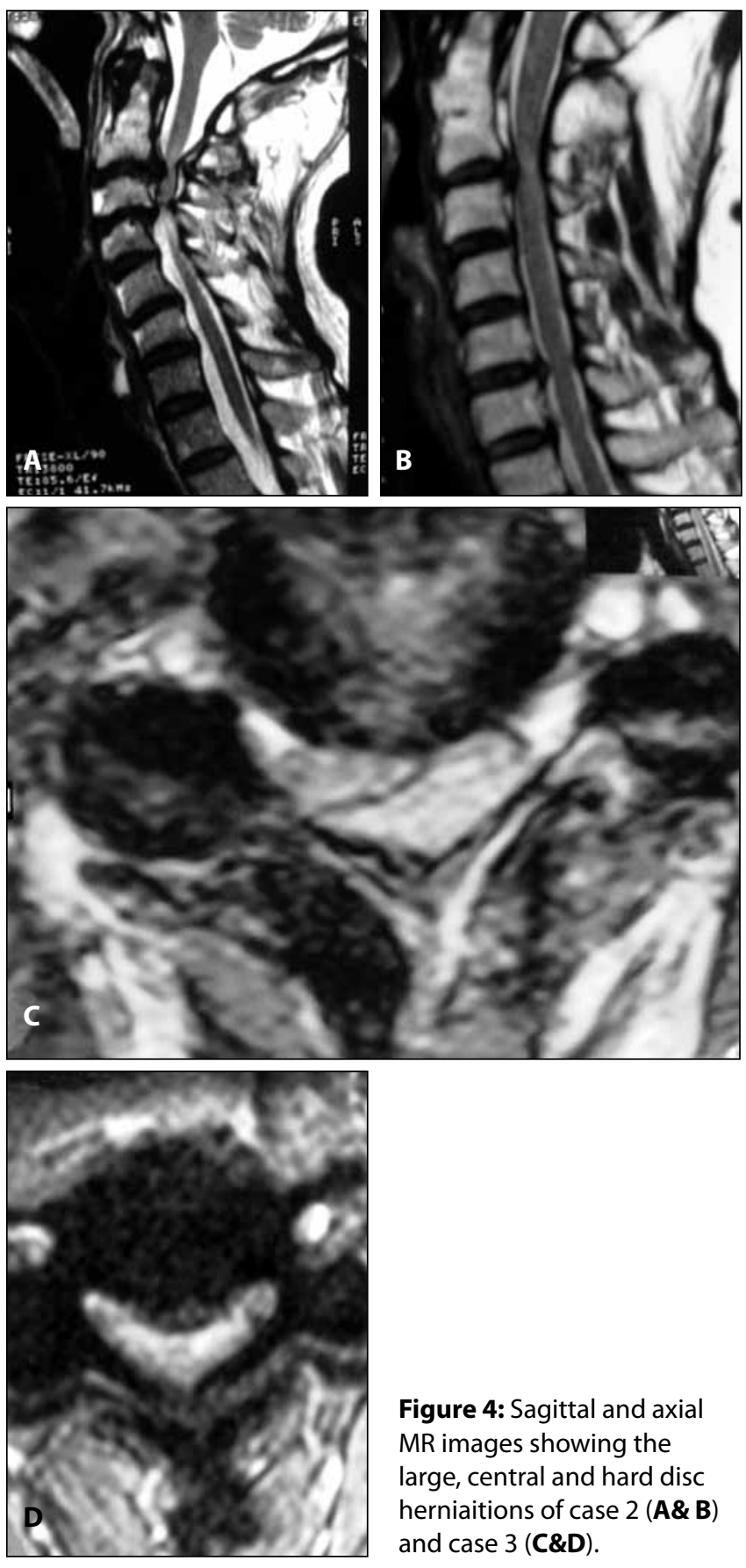

Figure 4: Sagittal and axial MR images showing the large, central and hard disc herniaitions of case 2 (A\& B) and case 3 (C\&D).

confirmed with the postoperative control MRI (2 cases) and CT (5 cases). Postoperative CT was obtained at the second year of follow-up in all patients. Except one lost case, Nurick scale was 1 in three and grade 0 in 1 patients postoperatively.

The symptoms were resolved in 3 patients and were unchanged in one patient. One patient $(66 \mathrm{y} / \mathrm{m})$ died due to myocardial infarction one week after the operation. There was no complaint after the operation and he was checked in the upper cervical region by CT. He was discharged after the postoperative 1st day. He complained of chest pain two days later and was admitted intensive care, but he died due to myocardial infarction and respiratory insufficiency one week after the operation in the early follow-up period.

Fusion was observed in all cases except the one who was lost to follow-up due to death.

\section{DISCUSSION}

Surgical approaches to the upper disc level have been performed for inflammatory, neoplastic, traumatic and infectious processes (5).

Surgery for disc disease at the C2-C3 level is extremely rare. Herniation at this level is exceptionally uncommon, and it is seen most often in elderly patients. In older patients, C2-C3 and C3-C4 are more mobile than other cervical disc levels. The overall incidence of $\mathrm{C} 2-\mathrm{C} 3$ herniation is $0.28 \%$ (5). The incidence of $\mathrm{C} 2-\mathrm{C} 3$ disc herniation among our cases was $0.45 \%$. There are only case reports in the literature about this entity. Chen et al. (5) have presented the largest case series. This is the second largest series of C2-C3 disc herniation. The literature contains only 13 publications reporting 24 cases of C2-C3 disc herniations (Table I), (1,3-5, 7,9,16, 19,20,22,). In these reports, 9 of 22 patients (41\%) had extruded disc material that had migrated upward to the retroodontoid region. Patients with lower cervical disc protrusions tend to exhibit root symptoms more commonly than myelopathic findings (24) but our cases exhibited myelopathic findings more often than root symptoms.

Rupture of the posterior longitudinal ligament can produce disc herniation or subsequent epidural migration in the upper cervical spine, which may be associated with inflammatory change and secondary fibrocartilaginous metaplasia (12). Retroodontoid migration was not observed in our cases.

These patients also have nonfocal symptoms such as headache, dizziness, and tinnitus. In C2-C3 disc protrusion, patients also characteristically present with predominant suboccipital discomfort rather than middle and lower neck pain. Radicular symptoms, however, are rarely isolated to a single dermatome.

The most predominant symptom may be perioral numbness and cruciate paralysis (5). There is a relationship between the sagittal diameter of the spinal canal and cervical myelopathy $(14,15)$. The sign of ascending dysesthesia in high cervical lesions, which indicates the greaterinvolvement of the centrally situated cervical fibers, may be due to its slow development $(6-8,11,17,21)$. Three of our patients had cruciate paralysis with perioral numbness. Schneider (23) urged an alert examination of facial sensation in all spinal injuries to identify damage to the fibers or cell bodies of the descending spinal tract of the trigeminal nerve, correspondingly, which begin in the pons and medulla and extend downwards to at least the C4 cervical segment. The cruciate paralysis, characterized by ipsilateral or bilateral upper extremity paresis, with minimal or no lower-extremity involvement, is often precipitated by injury localized to the upper cervical spine (6). 
Selecting the appropriate operative approach is the most important step for these patients. Despite many techniques described in the literature, there is still a lack of consensus concerning the optimum approach to the C2-C3 level. These techniques include Cloward's technique (9), anterior discectomy with auto/allograft fusion (3), transoral odontoidectomy with or without occipitocervical fusion $(3,5)$, the far lateral approach (16), the posterior transdural approach $(19,22)$, and the anterolateral extradural approach (25). Each of these techniques has advantages and disadvantages. Every spine surgeon can perform an anterolateral simple microdiscectomy with fusion. Anterior approaches are extremely difficult in patients with a short and thick neck. We performed anterior cervical disc surgery for two patients who had short necks. The main disadvantages of Cloward's technique and the anterior discectomy with fusion are the difficulty in exposing the C2-C3 level in depth, the need for excessive retraction, and the problems in instrumentation and placing a graft. Various complications related to the anterior approach have been reported in the upper cervical disc disease. In a review of 85 patients who had this approach to the upper cervical spine, $9(11 \%)$ had postoperative voice changes, and 3 (3.5\%) had permanent vocal cord paralysis (11, $17,19)$. Approach to the upper cervical spine in the central disc pathologies may be from both sides, right-handed persons generally prefer the right sided approach. Microsurgical approach is preferable to avoid injury to the accessory and hypoglossal nerves. Especially the hypoglossal nerve, which, coming from the cranial side, turns medially anterior to the external carotid artery, where it supplies the musculature of the tongue, has to be protected.

The superior thyroid artery, the lingual artery, and fascial artery, all of which arise from the external carotid artery may be ligated if necessary.

The superior laryngeal nerve, which gives off internal and external branches, originates from the vagus nerve and runs beneath the lingual and facial arteries to pass into the larynx; more cranially, the glossopharyngeal nerve, coursing medially from the base of the skull, passes into the superior constrictor muscle of the pharynx. Excessive traction of this nerve may lead to disorders in the sensitivity of the laryngeal mucosa and to paralysis of the cricothyroid muscle. If necessary, the irregularly coursing veins may be ligated.

If there is adequate knowledge of the anatomy, the approach described is easy and is associated with a low rate of complications.

There was no operation-related complication in our cases. One patient died due to myocardial infarction one week after the operation in the early follow-up period.

Based on this review and our own experience, disc herniations at the level of C2-C3 may result in a severe myelopathy, and cause severe neurological morbidity. Most of these patients are usually in the geriatric age group, and they have central and large disc herniations. The present study demonstrates that diagnosis and adequate anterior decompression may provide an excellent outcome.

\section{REFERENCES}

1. Antich PA, Sanjuan AC, Girvent FM, Simo JD: High cervical disC herniation and Brown-Sequard syndrome: $A$ case report and review of the literature. J Bone Jt Surg $(\mathrm{Br})$ 81:462-463, 1999

2. Bucciero A, Vizioli L, Cerillo A: Soft cervical disc herniation. An analysis of 187 cases. Neurosurg Sci 42:125-130, 1998

3. Campbell SF, Tannenberg AE, Mowat P: Transoral resection of retroodontoid disc sequestration: Case report and review of the literature. J Clin Neurosci 7:325-327, 2000

4. Chen TY, Lui T: Retrodental fibrocartilaginous mass. Report of a case. Spine 22:920-923, 1997

5. Chen TY: The clinical presentation of uppermost cervical disc protrusion. Spine 25:439-442, 2000

6. Clarck CR: Cervical spondylotic myelopathy: History and physical findings. Spine 13:347-349, 1988

7. Deshmukh VR, Rekate HL, Sonntag VK: High cervical disc herniation presenting with C-2 radiculopathy. J Neurosurg Spine 100:303-306, 2004

8. Engsberg JR, Lauryseen C, Ross PT, Hollman JH, Walker D, Wippold FJ: Spasticity, strength, and gait changes after surgery for cervical spondylotic myelopathy. Spine 28:131-139, 2003

9 Espersen JO, Buhl M, Eriksen EF, et al: Treatment of cervical disc disease using Cloward's technique. I. General results, effect of different operative methods and complications in 1,106 patients. Acta Neurochir (Wien) 70:97-114,1984

10. Haid RW: The soft cervical disc: Natural history and management. In: Cooper PR (ed) Degenerative Disease of the Cervical Spine. Chicago: AANS Publications, 1993: 113-124

11. Heeneman $\mathrm{H}$ : Vocal cord paralysis following approaches to the anterior cervical spine. Laryngoscope 83:17-21, 1973

12. Falcone S, Quencer RM, Green BA: Progressive posttraumatic myelomalacic myelopathy: Imaging and clinical features. AJNR 15:747-752, 1994

13. Jomin $M$, Lesoin F, Lozes G, et al: Herniated cervical discs: Analysis of a series of 230 cases. Acta Neurochir (Wien) 79:107-111, 1986

14. Law $M$, Bernhardt $M$, White A: Evaluation and management of cervical spondylotic myelopathy. J Bone Joint Surg 76:14201423, 1994

15. Lestini WF, Wiesel SW: The pathogenesis of cervical spondylosis. Cervical Orthop Rel Res 239:69-93,1989

16. Matsuno A, Nakashima $M$, Murakami $M$, Nagashima $T$ : Microsurgical excision of a retro-odontoid disc hernia via a far-lateral approach: Successful treatment of a rare cause of myelopathy. Case report. Neurosurgery 54:1015-1018, 2004

17. McAfee PC, Bohlman HH, Riley LH Jr, et al: The anterior retropharyngeal approach to the upper part of the cervical spine. J Bone Joint Surg Am 69:1371-1383, 1987

18. Murphy F, Simmons JCH, Brunson B: Surgical treatment of laterally ruptured cervical disc: Review of 648 cases, 1939 to 1972. J Neurosurg 38:679-683, 1973

19. Nishizawa S, Ryu H, Yokohama T, Uemura K: Myelopathy caused by retro-odontoid disc hernia: Case report. Neurosurgery 39:1256-1259, 1996 
20. Nishizawa S, Yokoyama T, Yokota N, Kaneko M: High cervical disc lesions in elderly patients: Presentation and surgical approach. Acta Neurochir (Wien) 141:119-126, 1999

21. O'Laoire SA, Thomas DGT: Spinal cord compression due to prolapse of cervical intervertebral disc herniation of nucleus pulposus, treatment in 26 cases by discectomy without interbody bone graft. J Neurousurg 59:847-853, 1983

22. Rosenberg WS, Rosenberg AE, Poletti CE: Cervical disc hernia presenting as a mass lesion posterior to the odontoid process: Report of two cases. J Neurosurg 75:954-959, 1991
23. Schneider RC, Crosby EC, Russo RH: Traumatic spinal cord syndromes and management. Clin Neurosurg 20:424-492, 1973

24. Stark RJ, Kennard C, Swash M: Hand wasting in spondylotic high cervical compression: An electromyographic study. Ann Neurol 9:58-62, 1981

25. Türe U, Güclü B, Naderi S: Anterolateral extradural approach for C2-C3 disc herniation: Technical case report. Neurosurg Rev 31(1):117-121, 2008 